\title{
STUDY OF THE EQUINE VIRAL ARTERITIS SEROCONVERSION AT HORSE STABLES IN THE TERRITORY OF VOJVODINA
}

\author{
Lazić Sava ${ }^{1}$, Lupulović Diana ${ }^{1}$, Lazić Gospava ${ }^{1}$, \\ Živulj Aleksandar ${ }^{2}$, Bugarski Dejan ${ }^{1}$, Petrović Tamaš ${ }^{1}$ \\ ${ }^{1}$ Scientific Veterinary Institute „Novi Sad“, Rumenački \\ put 20, 21000 Novi Sad, Republika Srbija \\ ${ }^{2}$ Veterinary Specialists Institute „Pančevo", Novoseljanski \\ put 33, 26000 Pančevo, Republika Srbija
}

\section{Abstract}

The paper presents the results of the study on equine viral arteritis presence in five horse stables in the territory of Vojvodina. The research encompassed analysis of clinical manifestation of the disease and seroconversion to equine viral arteritis throughout a two-year period (2012 and 2013). Analysis of clinical manifestations of the disease was performed according to the anamnestic data obtained from staff veterinarians on the stud farms. Prevalence of equine viral arteritis was determined by testing 204 blood serum samples from 102 horses. Sera samples were collected twice at oneyear interval, i.e. in 2012 and 2013, and examined by virus neutralization test. Seropositive results as well as seroconversion were obtained on one of the five investigated horse stables. At the stable with seropositive animals, 27 horses were serologically tested at one-year interval. Out of the total of 27 animals, antibody positive sera were obtained in 16 and 17 horses in 2012 and 2013, respectively. Antibody titre values ranged from 1 to $10 \log _{2}$, with average values of 3.11 and $3.15 \log _{2}$ in 2012 and 2013, respectively.

Key words: equine viral arteritis virus, horse stables, seroprevalence, seroconversion, virus neutralization test

\footnotetext{
${ }^{1}$ Sava Lazić, PhD, Principal Research Fellow, Correspoding author: lazic@niv.ns.ac.rs Diana Lupulović, PhD, Research Assistant, Gospava Lazić, MSc, Research Trainee, Dejan Bugarski, PhD, Research Associate, Tamaš Petrović, PhD, Senior Research Associate

${ }^{2}$ Aleksandar Živulj, Veterinary Specialist
} 


\title{
ISPITIVANJE SEROKONVERZIJE NA VIRUS VIRUSNOG ARTERITISA KONJA U ERGELAMA NA PODRUČJU VOJVODINE
}

\author{
Lazić Sava $^{1}$, Lupulović Diana ${ }^{1}$, Lazić Gospava ${ }^{1}$, \\ Živulj Aleksandar ${ }^{2}$, Bugarski Dejann ${ }^{1}$, Petrović Tamaš ${ }^{1}$ \\ ${ }^{1}$ Naučni institut za veterinarstvo „Novi Sad“, Rumenački \\ put 20, 21000 Novi Sad, Republika Srbija \\ ${ }^{2}$ Veterinarski specijalistički institut „Pančevo“, Novoseljanski \\ put 33, 26000 Pančevo, Republika Srbija
}

\section{Kratki sadržaj}

$\mathrm{U}$ radu su prikazani rezultati ispitivanja prisustva bolesti virusnog arteritisa konja u 5 ergela na teritoriji Vojvodine. Ispitivanja su vršena sa aspekta kliničkih manifestacija bolesti i serokonverzije na virus virusnog arteritisa konja tokom dve godine (2012. i 2013.). Analiza kliničke manifestacije bolesti vršena je na osnovu anamnestičkih podataka, dobijenih od veterinarskog osoblja ergela. Utvrđivanje virusnog arteritisa konja vršeno je ispitivanjem 204 uzorka krvnih seruma, metodom serum neutralizacije, prikupljanih od istih konja (102) tokom 2012. i 2013. godine, odnosno u intervalu od godinu dana. Seropozitivan nalaz, kao i serokonverzija, utvrden je na jednoj, od pet analiziranih ergela. Na ergeli u kojoj je utvrden seropozitivan nalaz, odnosno serokonverzija, serološki su ispitana 27 grla u intervalu od godinu dana. Od 27 serološki ispitanih konja, pozitivan nalaz utvrđen je kod 16 konja 2012., a 2013. godine kod 17 konja. Utvrđena vrednost titra antitela iznosila je od 1 do $10 \log _{2}$. Prosečna vrednost titra antitela 2012. iznosila je 3,11, a 2013. godine 3,15 $\log _{2}$.

Ključne reči: virus virusnog arteritisa konja, ergele, seroprevalenca, serokonverzija, serum neutralizacioni test

\section{INTRODUCTION}

Equine viral arteritis (EVA) is an infectious disease that can affect all ungulate species, as well as all horse categories. The disease is quite common worldwide causing severe health problems and considerable economic losses. The causal agent of the disease is the virus (Equine arteritis virus-EAV) from the family Arteriviridae. EAV is an enveloped, spherical virus of 50-70 nanometres $(\mathrm{nm})$ in diameter possessing single-stranded ribonucleic acid (RNA) 
genome of $12.7 \mathrm{~kb}$ (Balasuriya et al. 1999). The virus was isolated for the first time in 1953 in Bucyrus, Ohio state, U.S.A. (Nowotny, 2001). The name of the virus, arteritis, is based on the characteristic pathogenic activity observed in blood vessels. The virus replicates in muscle cells and endothelial cells of small blood vessels, predominantly arteries, and may lead to the range of inflammatory processes.

According to data from the literature (Holyoak et al, 2008), the disease has been reported in horse populations in all continents: North and South America, Europe, Asia, Australia and Africa. Only Iceland and Japan are considered EVA-free. A research that dates back to the 60ies and 70ies of the last century has established the following seroprevalence rates of EAV: Switzerland 11.3\%, England 2.3\%, Netherlands 14\% and Germany $1.8 \%$.

However, the investigation dated 1998 revealed seroprevalence rates of some $20 \%$ in Germany and about $2 \%$ in non-vaccinated horses in the U.S.A. (Holyoak et al 2008). In Austria, the EAV seroprevalence ranges between 10 and 12\%; however, on some stud farms the rate reaches even 100\% (Nowotny 2001). Seroprevalence rate in Anatolia (central Turkey) is 23.4\% (Bulut et al. 2012).

So far, the rate of EAV seroprevalence in the Republic of Serbia has not been confirmed, but the results reported by several authors (Petrović et al., 2002; Urošević et al., 2003; Lazić, 2013) indicated the presence of EAV infection in the country. In the Republic of Serbia, the research studies on EVA infection has been conducted only since the beginning of this century, i.e. in 2002, encompassing only imported horses in quarantines. More recently, the disease has been gaining more attention and numerous horse breeders have put efforts to initiate serological testing, foremost of breeding animals.

Infected horses shed the virus in nasal and ocular discharge, urine, aborted foetuses and sperm (stallions). The virus can cause a range of health disorders in horses, including interstitial pneumonia, panvasculitis with consequent oedema predominantly in eye lids, abdomen, distal parts of the limbs, preputium and scrotum, thrombosis associated with bleeding, necrosis in lymph nodes and kidneys, abortions and inflammation of accessory sex glands. Sometimes, the infection may pass without developing any health status disorders ( $\mathrm{Del}$ Piero, 2000). Infected stallions are potential natural reservoir of the virus. If the virus affects accessory sex glands, stallions remain infected for life and frequently shed the virus in the semen (Del Piero, 2000; Nowotny, 2001; Holyoak et al 2008). Testing the possibility of virus spreading through the semen and its detection in the semen was the topic of interest of numerous researches. Development of modern laboratory diagnostic methods, such as molecular biology 
assays, gave rise to more intense research in this field, which have confirmed that seropositive stallions shed the EAV in their semen (Ramina et al., 1999; Balasuriya et al., 2002; Mankoč et al., 2002; Guthrie 2003; Chenchev et al., 2010)

\section{MATERIAL AND METHODS}

\section{Samples}

Blood samples were collected in five horse stables from the territory of Vojvodina Province. The horse stables were designated with letters A - E. The sampling encompassed the same horse population and was performed twice at one-year interval, i.e. in 2012 and 2013. Samples were collected by venipuncture of the Vena jugularis into Vacutainer tubes, and serum separation was performed after spontaneous coagulation. Anamnestic data on health status during the past 3-year period were recorded for each horse subjected to blood sampling. Thus, 102 blood samples of horses were obtained in 2012, and the same number of samples in 2013 so, in total 204 blood serum samples from five horse stables were collected and examined on anti-EAV antibodies presence.

The breed structure of horses at the examined farms was rather diverse, yet several breeds were dominant at particular farms: Lipizzan breed at farms $\mathrm{A}$ and $\mathrm{E}$, English pureblood and half-blood breed at farms B and C and Lipizzan and English pureblood and half-blood as well as Nonius breed at farm D. At all investigated stud farms, the breeding systems were in accordance with common practices of horse farming. The stallions are housed in individual boxes, as well as highly pregnant mares or pospartum mares. Other horse categories are raised in groups. Throughout the year, the horses from all farms participate at various competitions, such as galopp races or parade competitions.

\section{Serum samples analysis}

Identification of anti-EAV antibodies in blood serum samples was performed by the method of virus neutralization, according to procedure set out by OIE Terrestrial Manual, Chapter 2.5.10, 2008. Virus neutralization was performed by using rabbit-kidney cell line RK-13 and Bucyrus strain of EAV. According to the OIE Terrestrial Manual, antibody titre values $\geq 2 \log _{2}$ are considered as seropositive result. Animals that do not have a certified history of vaccination against EVA are considered infected, i.e. such stallions are considered potential source of infection. 


\section{RESULTS AND DISCUSSION}

To provide a clear overview of our findings, the obtained results are presented in Tables. The present study encompassed 102 horses (averagely one fourth) out of the total of 355 horses (in 2012) and 386 horses (in 2013) that were raised in 5 examined horse stables (Table 1.). Presence of anti-EAV antibodies was obtained in animals from one horse stable (E), where 62 and 72 horses were raised during 2012 and 2013, respectively. At this farm, 27 horses were examined during the two aforementioned years. Presence of anti-EAV antibodies was confirmed in $16(59.26 \%)$ examined horses in 2012 and in 17 (62.96\%) examined horses in 2013.

Table 1. Overview of examined horses according to the farm and EVA antibody finding

\begin{tabular}{|c|c|c|c|c|c|}
\hline \multirow[b]{2}{*}{ No. } & \multirow[b]{2}{*}{$\begin{array}{l}\text { Horse } \\
\text { stables }\end{array}$} & \multirow[b]{2}{*}{$\begin{array}{c}\text { No. of } \\
\text { horses in } \\
\text { stables }\end{array}$} & \multirow{2}{*}{$\begin{array}{c}\text { No. of } \\
\text { examined } \\
\text { horses in } \\
\text { stables }\end{array}$} & \multicolumn{2}{|c|}{ Result } \\
\hline & & & & Positive & Negative \\
\hline 1 & A & 34 & 12 & 0 & 12 \\
\hline 2 & B & 82 & 23 & 0 & 23 \\
\hline 3 & $\mathrm{C}$ & 78 & 20 & 0 & 20 \\
\hline 4 & $\mathrm{D}$ & 120 & 20 & 0 & 20 \\
\hline 5 & $\mathrm{E}$ & 72 & 27 & $\begin{array}{c}16^{\star} \\
(59.26 \%) \\
17^{\star *} \\
(62.96 \%)\end{array}$ & $\begin{array}{c}11^{\star} \\
(40.74 \%) \\
10^{\star \star}(37.04)\end{array}$ \\
\hline \multicolumn{2}{|c|}{ Total } & $386^{* *}$ & 102 & $\begin{array}{c}16^{\star} \\
(15.67 \%) \\
17^{\star \star} \\
(16.67 \%)\end{array}$ & $\begin{array}{c}86^{\star} \\
(84.31 \%) \\
85^{\star *} \\
(83.33 \%)\end{array}$ \\
\hline
\end{tabular}

$\star 2012$

$* * 2013$

Equine arteritis virus infection has been established only on farm E. Thus, the analysis of the results obtained on this stud farm can illustrate the effects of this infection on the health status of horses, incidence of the infection within different horse categories as well as the potential for virus dissemination on the horse farm. 
According to anamnestic data obtained from staff veterinarians and stud farm manager, during the past 3- and 4-year periods clinical symptoms indicating equine viral arteritis were not observed. Abortions were recorded only sporadically and were mainly associated with twin-embryo pregnancies. Frequently, mares from other stables were introduced to the stud farm for breeding, mostly lacking the documents of serological testing for sexually transmitted infectious agents.

The EVA antibody titre values established during 2012 and 2013 in all investigated horses are presented in Table 2 . The analysis of the results indicate virus circulation within the stable, and that the most probable route of virus spread was sexual transmission. Analysis of mating schedule revealed that seropositive stallions were used for mating, therefore an increased number of mares become infected with this virus. The number of seropositive horses increased for one animal in 2013, i.e. from 16 seropositive animals in 2012 to 17 seropositive animals in 2013. The established antibody titre values did not vary significantly; however, the average EAV antibody titre value were somewhat higher in $2013\left(3.15 \log _{2}\right)$ as compared to $2012\left(3.11 \log _{2}\right)$ indicating permanent circulation of the virus on this farm. Still, the seroprevalence to EAV dropped from $25.81 \%$ in 2012 to $23.61 \%$ in 2013 , which is due to the increased number of horses (10 animals) on farm E in 2013.

Table 2. Overview of anti-EAV antibody finding in horse blood sera on farm $\mathrm{E}$ in 2012 and 2013

\begin{tabular}{|c|c|c|c|c|}
\hline \multirow{2}{*}{ No. } & \multirow{2}{*}{ Sample No. } & \multirow{2}{*}{ Horse category } & \multicolumn{2}{|c|}{ Antibody titre (log, } \\
\cline { 4 - 5 } & & 2012 & 2013 \\
\hline 1 & $1-21751$ & Stallion & 7 & 5 \\
\hline 2 & $2-01452$ & Stallion & 0 & 0 \\
\hline 3 & $3-09426$ & Stallion & 2 & 2 \\
\hline 4 & $4-22154$ & Stallion & 9 & 9 \\
\hline 5 & $6-22912$ & Stallion & 0 & 0 \\
\hline 6 & $16-02828$ & Stallion & 2 & 3 \\
\hline 7 & $6-03179$ & Gelding & 0 & 0 \\
\hline 8 & $15-00128$ & Gelding & 0 & 0 \\
\hline 9 & $8-13745$ & Mare & 0 & 0 \\
\hline 10 & $9-23714$ & Mare & 0 & 0 \\
\hline 11 & $10-11623$ & Mare & 4 & 4 \\
\hline 12 & $11-16872$ & Mare & 4 & 4 \\
\hline 13 & $12-14794$ & Mare & 4 & 4 \\
\hline 14 & $13-02702$ & Mare & 5 & 5 \\
\hline 15 & $31-03459$ & Mare & 0 & 7 \\
\hline 16 & $17-33372$ & Mare & 5 & 5 \\
\hline
\end{tabular}




\begin{tabular}{|c|c|c|c|c|}
\hline \multirow{2}{*}{ No. } & \multirow{2}{*}{ Sample No. } & \multirow{2}{*}{ Horse category } & \multicolumn{2}{|c|}{ Antibody titre $\left(\log _{2}\right)$} \\
\cline { 4 - 5 } & & & 2012 & 2013 \\
\hline 17 & $19-03036$ & Mare & 5 & 6 \\
\hline 18 & $20-02936$ & Mare & 1 & 3 \\
\hline 19 & $21-24452$ & Mare & 5 & 5 \\
\hline 20 & $22-17332$ & Mare & 6 & 6 \\
\hline 21 & $23-02961$ & Mare & 7 & 7 \\
\hline 22 & $24-34861$ & Mare & 0 & 0 \\
\hline 23 & $25-27196$ & Mare & 6 & 3 \\
\hline 24 & $26-05112$ & Mare & 10 & 7 \\
\hline 25 & $27-14166$ & Mare & 0 & 0 \\
\hline 26 & $29-02567$ & Mare & 2 & 0 \\
\hline 27 & $30-02830$ & Mare & 0 & 0 \\
\hline \multicolumn{3}{|c|}{ Average antibody titre value } & 3.11 & 3.15 \\
\hline
\end{tabular}

Assessment of seropositive results to EAV on stud farm E according to horse category (Table 3.) reveals an increase in number of seropositive animals in the category of mares, which, according to the obtained anamnesis data, most probably results from mating with seropositive stallions. EAV antibody titre value in the mare marked 31-03459 was $7 \log _{2}$ in 2013 , whereas the same animal was seronegative in 2012 (Table 2.). This mare was mated by a seropositive shedder stallion during mating season 2012/2013, thus supporting the suspicion of sexual transmission of this viral infection in the stable.

Table 3. Number of horses with positive anti-EAV antibody finding on farm $\mathrm{E}$ in 2012 and 2013, according to horse categories

\begin{tabular}{|c|c|c|c|}
\hline \multirow{2}{*}{ Category } & \multirow{2}{*}{$\begin{array}{c}\text { Number of exa- } \\
\text { mined animals }\end{array}$} & \multicolumn{2}{|c|}{$\begin{array}{c}\text { Number of anti-EAV } \\
\text { antibody positive animals }\end{array}$} \\
\cline { 3 - 4 } & & 2012 & 2013 \\
\hline Stallions & 6 & 4 & 4 \\
\hline Geldings & 2 & 0 & 0 \\
\hline Mares & 19 & 12 & 13 \\
\hline Total & 27 & 16 & 17 \\
\hline
\end{tabular}

Sexual transmission and dissemination of the infection in stud farm E can be better understood by analyzing the distribution of established anti-EAV antibody titre values as well as the mating schedule records. Mating of seropositive stallions during several seasons results in persistence and dissemination 
of the infection in this stud farm. Distribution of the established antibody titre values according to horse categories is presented in Tables 4. and 5. for 2012 and 2013, respectively.

Table 4. Distribution of the established anti-EAV antibody titre values according to horse categories in stud farm E in 2012

\begin{tabular}{|c|c|c|c|c|c|c|c|c|c|c|c|c|c|}
\hline \multirow{2}{*}{ Category } & \multirow{2}{*}{$\begin{array}{l}\text { No. of } \\
\text { exam. } \\
\text { animals }\end{array}$} & \multicolumn{11}{|c|}{ Antibody titre $\left(\log _{2}\right)$} & \multirow{2}{*}{$\begin{array}{l}\text { Average } \\
\text { antibody } \\
\text { titre value }\end{array}$} \\
\hline & & 0 & 1 & 2 & 3 & 4 & 5 & 6 & 7 & 8 & 9 & 10 & \\
\hline Stallions & 6 & 2 & $--^{*}$ & 2 & - & - & - & - & 1 & - & 1 & - & 3.33 \\
\hline Geldings & 2 & 2 & - & - & - & - & - & - & - & - & - & - & 0 \\
\hline Mares & 19 & 6 & 1 & 1 & - & 3 & 4 & 2 & 1 & - & - & 1 & 3.37 \\
\hline Total & 27 & 10 & 1 & 3 & - & 3 & 4 & 2 & 2 & - & 1 & 1 & 3.11 \\
\hline
\end{tabular}

* - negative antibody finding

Table 5. Distribution of the established anti-EAV antibody titre values according to horse categories in stud farm E in 2012

\begin{tabular}{|c|c|c|c|c|c|c|c|c|c|c|c|c|c|}
\hline \multirow{2}{*}{ Category } & \multirow{2}{*}{$\begin{array}{l}\text { No. of } \\
\text { exam. } \\
\text { animals }\end{array}$} & \multicolumn{11}{|c|}{ Antibody titre $\left(\log _{2}\right)$} & \multirow{2}{*}{$\begin{array}{l}\text { Average } \\
\text { antibody } \\
\text { titre value }\end{array}$} \\
\hline & & 0 & 1 & 2 & 3 & 4 & 5 & 6 & 7 & 8 & 9 & 10 & \\
\hline Stallions & 6 & 2 & $-x^{*}$ & 1 & 1 & - & 1 & - & - & - & 1 & - & 3.17 \\
\hline Geldings & 2 & 2 & - & - & - & - & - & - & - & - & - & - & 0 \\
\hline Mares & 19 & 6 & - & - & 2 & 3 & 3 & 2 & 3 & - & - & - & 3.47 \\
\hline Total & 27 & 10 & - & 1 & 3 & 3 & 4 & 2 & 3 & - & 1 & - & 3.15 \\
\hline
\end{tabular}

* - negative antibody finding

However, despite positive anti-EAV antibody findings, analysis of general health status of both stallions and mares during 2012 and 2013 revealed neither health status disorders nor failed fertilizations and abortions. The foaling occurred within normal time period, and foals did not manifest any health disorders. These data indicate that EAV infection can persist without health disorders manifestation, which is in accordance with the data reported by other authors (Del Piero, 2000; Urošević et al., 2003; Lazić et al., 2013).

Analysis of the results obtained in this research revealed that they well 
correspond with the data from the literature. High seroprevalence on some horse stables reported by Nowotny (2001) and several other researchers was due to an unobstructed virus transmission within the farm. Virus shedding in the semen of seropositive stallions is frequently reported by numerous authors (Mankoč et al. 2002; Chenchev et al. 2010), thus seroconversion in mares inseminated with semen originating from seropositive stallions was expected result at the stable $\mathrm{E}$.

\section{CONCLUSIONS}

Out of the 5 horse stables with in total 355 horses (2012) and 386 horses (2013) encompassed by this research, EAV infection was confirmed at one stable. In that seropositive stable the established antibody titre values did not vary significantly; however, the average EAV antibody titre value were somewhat higher in $2013\left(3.15 \log _{2}\right)$ as compared to $2012\left(3.11 \log _{2}\right)$ indicating permanent circulation of the virus on this farm. According to the obtained results, we may conclude that sexual transmission was the route of virus transmission and dissemination in this stud farm.

\section{ACKNOWLEDGEMENT}

The presented work is part of the research done in the framework of the projects TR31084 and TR31071 granted by the Ministry of Education and Science of the Republic of Serbia

\section{LITERATURA}

1. Balasuriya U.B., Hedges J.F., Nadler S.A., Mccollum W.H., Timoney P.J., Maclachlan N.J.: Genetic stability of equine arteritis virus during horizontal and vertical transmission in an outbreak of equine viral arteritis. Journal of General Virology, 80, 1949-1958, 1999.

2. Balasuriya U.B., Leutenegger M.Ch., Topol B.J., McCollum H.W., Timoney P.J., Maclachlan N.J.: Detection of equine arteritis virus by real-time TagMan reverse transcription-PCR assay. Juranal of Virological Methods, $101,21-28,2002$.

3. Bulut O., Yavru S., Yapici O.K.M., Avei O.: The Serological Investigation of Equine Arteritis Infection in Central Anatolia of Turkey. Journal of Animal and Veterinary Advances, 11, 7, 924-926, 2012. 
4. Chenchev I., Polychronova L., Chakarova S., Genova I.: The real time PCR for detection of Equine Arteritis Virus. Arhiv veterinarske medicine, 3, 1, 3-11, 2010.

5. Del Piero F.: Equine Virus Arteritis. Veterinary Patholgy, 37, 287-296, 2000.

6. Guthrie A.J, Howell P.G, Hedges J.F, Bosman A.M, Balasuriya U.B, McCollum W.H, Timoney P.J, Maclachlan N.J.: Lateral transmission of equine arteritis virus among Lipizzaner stallions in South Africa. Equine Veterinary Journal, 35, 596-600, 2003.

7. Holyoak R.G., Balasuriya U.B., Broaddus C.C. Timoney P.J.: Equine viral arteritis: Current status and prevention. Theriogenology, 70, 3, 403-414, 2008.

8. Kosec M., Hostnik P.: Detection of Equine Arteritis Virus in semen of seropositive stallions. Veterinarska Novina 28, 2, 213-219, 2002.

9. Lazić S., Lupulović D., Lazić G., Gavrilović P., Bugarski D., Petrović T.: Research on incidence and effects of viral arteritis on health status of horses at stables. In: Proceedings, 10th International Symposium Modern Trends in Livestock Production, Belgrade, 2 - 4 October, 2013, Institute for Animal Husbandry, Beograd, Institute for Animal Husbandry, 2013, Str.1252-1259

10. Mankoč S, Barlič-Maganja D, Grom J. Toplak I., Klobučar M., Nowotny N.: Virusni arteritis konja. U: Zbornik radova i kratkih sadržaja, 13. Savetovanje veterinara Srbije, 2001, 33-36.

11. OIE Terrestrial Manual: Chapter 2.5.10, 2008.

12. Ramina A., Valle D.L., De Mas S., Tisato E., Zuin A., Renier M., Cuteri V., Valente C., Cancellotti M.F.: Detection of equine arteritis virus in semen by reverse transcriptase polymerase chain reaction-ELISA. Comparative Immunology, Microbiology \& Infectious Diseases, 22, 187-197, 1999.

13. Urošević M., Nowotny N., Đuričić B., Trailović R. D., Petrović T., SavićJevđenić S.: Indirektno dokazivanje prisustva virusnog arteritisa konja (EAV) kod pastuva u jednom zapatu, Savremena poljoprivreda Novi Sad, $52,3-4,503-507,2003$.

Received / Primljeno: 15.11.2013. Accepted / Odobreno: 08.12.2013. 